\title{
Adapting to climate variability: the views of peasant farmers in Nepal
}

\author{
Sudarshan Chalise \\ Griffith Business School, \\ Griffith University, \\ 170 Kessels Road, Nathan QLD 4111, Australia \\ Email: sudarshan.chalise@griffithuni.edu.au
}

\section{Tek Narayan Maraseni*}

Australian Centre for Sustainable Catchments, University of Southern Queensland, Toowoomba, Queensland, 4350, Australia

Email: Tek.Maraseni@usq.edu.au

\section{Jerry Maroulis}

Soil Physics and Land Management (SLM) Group, Wageningen University, Droevendaalsesteeg 4, 6708 PB Wageningen, The Netherlands

Email: Jerry.Maroulis@usq.edu.au

\section{Biographical notes}

Sudarshan Chalise is a PhD Fellow (full scholarship) in Griffith Business School, Griffith University, Australia. He completed double master and an MPhil from Tribhuvan University, Nepal. His research focuses on economics of climate change, computable general equilibrium (CGE) modelling and applications, land use change, sustainable development, and ecological economics. He is the author of the book entitled "combating climate change: a real threat to Nepal” published by Lambert Academic Publishing, Germany.

Dr Tek Maraseni is the Deputy Director (Operations) with the Australian Centre for Sustainable Catchments and is working in the areas of climate change adaptation, mitigation, and greenhouse gas emissions accounting/modelling. He completed a double BSc (Science and Forestry) in Nepal (1985-1991), and gained his MSc in Natural Resources Management from Asian Institute of Technology, Thailand, where he was awarded a gold medal (GPA 4/4) for his MSc, and a PhD from Australia. He has produced over 90 publications including two books in the last eight years. His published work has been recognized by national and international fellowships/grants/awards. During this time

*Corresponding author Email: maraseni@usq.edu.au 
he has supervised eight $\mathrm{PhD}$ students, marked $\mathrm{PhD}$ theses and reviewed journal articles in ten international journals.

Dr Jerry Maroulis is currently a lecturer in the Soil Physics and Land Management (SLM) Chair Group at Wageningen University, The Netherlands. Prior to this, he was a senior lecturer in the Faculty of Education at the University of Southern Queensland and also Deputy Director of the Australian Centre for Sustainable Catchments (ACSC). He has also worked as a senior environmental consultant, focused largely upon a range of soil-erosion based research consultancies. Despite a PhD in fluvial geomorphology, he has published extensively in a range of disciplines including physical geography, Quaternary science, sustainability, science and online education, and environmental sciences.

\begin{abstract}
There are growing concerns, especially from farmers in rural mid-east Nepal, about mainstreaming locally-led climate adaptation strategies. Using a bottom-up approach, we analysed the bio-physical and socio-economic impacts on Nepalese agriculture from three focus group discussions and a survey of 60 peasant farmers to identify the relevant climate change impacts which were used to investigate how farmers' practices overcome any climate-based barriers. The results suggest that farmers are partially able to minimize the impacts of climate-based barriers whereas they have difficulty in coping with non-climatic barriers. The results emphasise the role of government and other stakeholders in locallyled adaptation (not only in mitigation) as an avenue to combat the negative impacts of climate-based variability.
\end{abstract}

Keywords: climate variability, farmer perception, locally-led adaptation 


\section{Introduction}

Human-induced climate change is unavoidable (Esham \& Garforth, 2013), and is likely to have a significant impact on many developing countries such as Nepal. Whilst fluctuations in climatic patterns increase farmer vulnerability, their belief in divine power represents a major social barrier to locally-led climate adaptation. This issue was also identified by the Intergovernmental Panel on Climate Change (IPCC, 1996), where people in developing countries such as Nepal believe bad things result from divine intervention, and as such, they lack the courage to challenge the perceived 'divine power'.

Nepal's economy is largely based on agriculture, with infrastructure development, education and health projects representing the key national priorities rather than climate change. However, $80 \%$ of Nepalese households are rural farms/regional households generating only 50\% of their income from agricultural sources (Karki, 2008); insufficient to provide a secure livelihood. Small farmers (peasant farmers) in Nepal are generally conscious of the adverse effects of climate change (Chalise, 2012), but other factors including poverty and illiteracy result in low adaptive capacity as evident in most developing countries (Malla, 2008). Guzman (2006) argues that current global solutions to climate change problems focus more on improvement than adjustment, and remain largely unavailable to the poor. Fischer et al. (2005) claim that developing countries are more vulnerable to climate change impacts than most advanced economies, as they are already

overburdened by insufficient funds to tackle the many emerging climate change challenges. 
According to Saito (2007), intensifying buoyancy through adaptation measures is fundamental to ensuring that economic development efforts are not compromised by climate change. Similarly, Qiu and Prato (2012) maintain that the negative effects of climate variability, such as drastic changes in temperature and rainfall trends, adversely affect crop production and farm earnings. The Food and Agricultural Organization (FAO, 2004) claims that changes in climate give rise to variable agro-ecological zones, diseases and pests, which can have a considerable detrimental impact on farming. Agriculture in Asia is in a poor state due to abnormal floods, longer and more severe droughts, largescale landslides and frequent and severe thunderstorms (Chaudhary et al., 2011; Lashkari, Alizadeh, Rezaei, \& Bannayan, 2012).

With the help of focus group discussions and a survey of peasant farmers in rural mid-east Nepal, this paper explores local farmers' adaptation strategies to climate variability.

\section{Rationale for Research and Problem Statement}

Developing countries including Nepal are faced with many problems in managing climate change. For centuries, Nepalese peasant farmers have relied on their knowledge of local conditions to cope with environmental change (Chaudhary et al., 2011). This is largely due to inadequate institutions and poor technologies for collecting information, which results in ill-informed and poor policy decisions. Governments have limited budgets to fund both research to provide robust data, and in providing support to farmers to adapt to climate change. 
Family/small-scaled farming rather than commercial initiatives represents the norm in Nepal. For example, $78 \%$ of farm holdings in Nepal produce crops only for home consumption, $21 \%$ for market and home consumption, and a meagre $1 \%$ as a cash crop, all on an average land-holding of 0.8 ha (Karki, 2008). In this agro-economic context, a topdown model of adaptation strategies (c.f. Al-Amin and Filho, 2012; Jenny and Egal, 2002) is not an effective way to proceed, as the projected detrimental effects of climate change, will have major impacts on an already very fragile Nepalese farming system which economically, socially and environmentally could be devastated. Thus, a bottom-up approach to adaptation, utilising traditional foundations yet incorporating scientific strategies, is proposed in this model. Also, with the previously used anticipatory measures of adaptation at the policy level may be challenging and inefficient (Bhandari, 2013), with the outcomes potentially being miscommunicated.

In light of these constraints, farmers may provide an alternative source of information for informing and guiding decision makers. However, it is uncertain whether information based on farmer's experiences represents a reliable source of information as little is known about how farmers are responding to climate change. There have been a few relevant demographic studies (Agrawala et al., 2003), however, they are inadequate in terms of investigating: (i) people's perception of climate change and their adaptation strategies at the local level; (ii) factors that enforce farmers' decision to adapt to climate change; and (iii) knowledge gaps that remain as barriers to adaptation. The purpose of this study was to 
address the knowledge problems and contribute to the climate change literature, via two research questions:

1. What are the impacts and the ways of adapting to climate variability as perceived by peasant farmers?

2. What are the climatic and non-climatic factors influencing climate change adaptation in Nepalese agriculture?

\section{Literature Review}

Nepal is more susceptible to climate change than any other Asian developing country due to its steep mountainous terrain resulting in limited arable lands, a fragile agrarian-based economy and high levels of poverty. The average annual increase of air temperature by $0.04^{0} \mathrm{C}$ (Malla, 2008) will result in erratic precipitation, and greater soil erosion and droughts. The current rate of annual soil erosion is estimated at $\sim 24$ million $\mathrm{m}^{3}$, or $1.7 \mathrm{~mm}$ of fertile soil (Ministry of Agriculture and Co-operatives, 2005), which critically highlights the need for locally-led adaptation to parallel mitigation strategies. Moreover, the prospect of a future with prolonged droughts could result in rapid evaporation and ultimately drying of important water bodies in the mid-eastern parts of Nepal (Gurung and Bhandari, 2005). Thus it is critically important to motivate researchers now to address future water availability and cleanliness of drinking water issues. The IPCC (1998) also predicts that there will be a lack of drinking water and food throughout Asia because of uncontrolled climate change in coming decades. As a result, the report predicted, >50 million additional people, from a total of 870 million people, will regularly face hunger by

2020. Given these dramatic scenarios and the consequent impacts on the livelihood of 
Nepalese farmers, could locally-led adaptation measures minimise the gap between food demand and supply? On the one hand, Jenny and Egal (2002) argue that traditional food security measures are not sufficient to ensure food availability due to declining soil fertility and the impacts of climate change. Burton (1996) supports this view stating that farmers' current knowledge of adaptation and adaptive capacity at the global level is insufficient to formulate appropriate local level adaptation options and strategies, which is partially due to the low adaptive capacity of developing countries (Al-Amin and Filho, 2012). Thus, harnessing climate-related information at the local level is extremely important.

This discussion highlights two types of studies focussing on climate change issues in Nepalese agriculture: agronomic and bio-physical. Many micro-econometric studies have paid attention to quantifying adaptation costs with increases in agricultural productivity (Bryan et al., 2013). For example: Karki (2008), Gurung and Bhandari (2005) and Jenny and Egal (2002) all investigated 'vulnerability due to climatic factors'. However, they paid negligible attention to non-climatic factors such as socio-economic and other factors. In contrast, the Government of Nepal relied on short term results of bio-physical studies (Karki \& Gurung, 2012). The studies capturing environmental factors only, without addressing socio-economic issues, will lead to inefficient policy framing (Deressa, Hassan, Ringler, Alemu, \& Yesuf, 2009). This is also because farmers have different levels of economic status that determine their level of perception (Claessens et al., 2012). In this study, therefore, we captured the farmer's responses to non-climatic barriers to 
combat climate change. This lens of analysis is critically important as there are numerous relevant indirect climate change impacts for developing countries.

\section{Approaches to Investigating the Case Study Sites}

Three case studies were conducted in mid-eastern Nepal (Fig. 1): Bethan Village Development Committee (VDC) of Ramechhap District, Panchkhal VDC of Kavre District, and Duwakot VDC of Bhaktapur District, with populations of 6,810, 13,387 and 8,176, respectively. Within these VDCs, farmer dependency on small-scale farming was the key sampling criteria. Moreover, these three sites were selected for two reasons: (1) measurements and data for temperature and precipitation were easily accessible from meteorological stations; and (2) there were huge variations in rainfall patterns in these sites over 1990-2010, though they have similar agricultural patterns - as the sites were purposively selected to analyse farmers' behaviours in relation to crop rotation and changes in agricultural pattern.

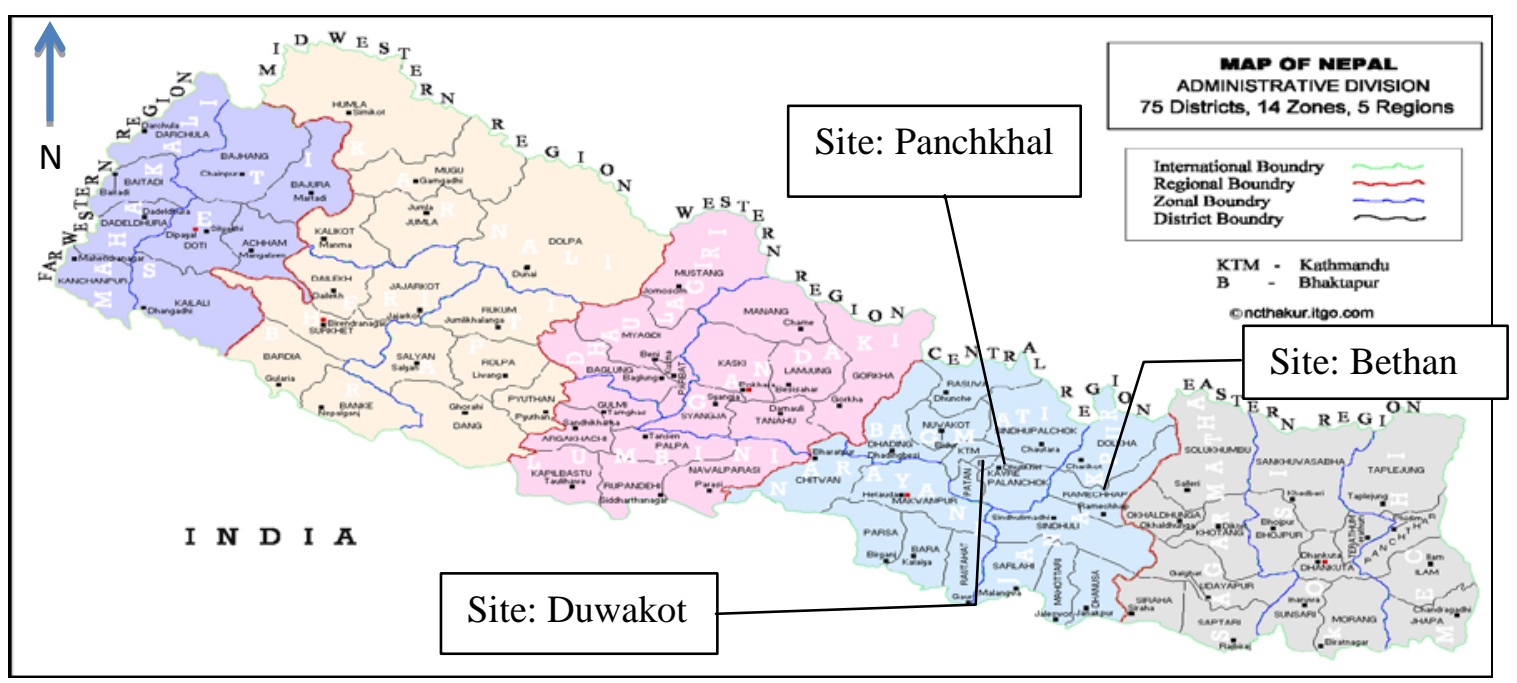

Figure 1: Location of the three Village Development Committees (VDC) study sites in mid-eastern Nepal. 
The major cereal crops grown in the study sites are rice, maize (corn), millet, pulses and potatoes, which are sufficient to sustain farmers and their families for 3-8 months, depending on the location, type and size of land, and seasonal factors. A typical diet for these farmers consists mostly of maize, finger millet, and buckwheat. Rice, however, is the preferred food and is eaten with vegetables and lentil soup, when rice is available. Typical intercropping patterns practised in the study sites were paddy-wheat-paddy; paddy-maize-paddy; paddy-vegetable-paddy; paddy-potato-paddy; or paddy-oilseedpaddy. Generally, agricultural land that is owned by local farmers is less productive due to the steep topography (hilly areas), lack of irrigation and limited availability of manure/fertilizer.

Livestock farming is common but is at a subsistence level. Therefore, livestock manure is insufficient to sustain high intensity cropping. In the past, farmers collected fodder and forage grasses from the forests for livestock; but this practice is slowly disappearing, largely due to the degradation of forests and strict restrictions placed on the collection of such materials. In all sites, compost was made from crop residues, but this is now used as food for livestock. Given that agricultural extension officials have limited options to assist farmers to improve productivity within such a resource-poor environment (Gurung and Bhandari, 2005), means that farmers' activities have focussed upon improved crop varieties.

A case study approach was deployed to harness detailed and valuable insights and understandings about the research topic (Yin, 2003). For each study area, we aimed, 
during a preliminary visit in March 2010, to capture each of the three study areas’ natural physiographical characteristics, communal structure and socio-economic conditions. We conducted focus group discussions (FGD) with older local farmers (representing the older generation) and high school students (representing the younger generation who are helping their parents in farming), to capture the views of two generations; representing the past, present and future of the farming community at each study site. Respondents were given a questionnaire, comprising structured and unstructured questions, focussing upon their farming system, and their views on the agricultural economy, their understanding about climate change and climate variability, and their impact.

The study sampled 20 peasant farmers and 10 high school students from each site. The respondents' perception was triangulated with secondary sources of meteorological data obtained from the Government of Nepal's Department of Hydrology and Meteorology (DHMN). Triangulation is extremely useful in cross-checking results to increase the validity and reliability of the data (Bryman, 2008).

\section{Results}

\section{1. a. Variability in Climate Parameters}

This study collected both long-term temperature and rainfall data, and the perception of local people to three categories of climate-based issues (changes in average temperature, precipitation and their respective impacts on their specific agricultural activities). Temperature and rainfall data for all VDCs were collected from the DHMN, but 
temperature data for Bethan VDC were not available. The unavailability of temperature data in Bethan VDC created delimitation in generalising the respondents' overall views.

Average minimum and maximum temperatures from 1990 to 2009 show an increasing temperature trend for both Panchkhal and Duwakot VDCs (Fig. 2), in-spite of the large variability in inter-annual temperatures. The maximum temperature of the Panchkhal site increased by $1.2{ }^{\circ} \mathrm{C}$ between 1990 and 2009, while the Duwakot site increased by $1{ }^{\circ} \mathrm{C}$. During the same period, minimum temperatures of Panchkhal and Duwakot rose by 0.75 ${ }^{\circ} \mathrm{C}$ and $1.2{ }^{\circ} \mathrm{C}$, respectively (Fig. 2).

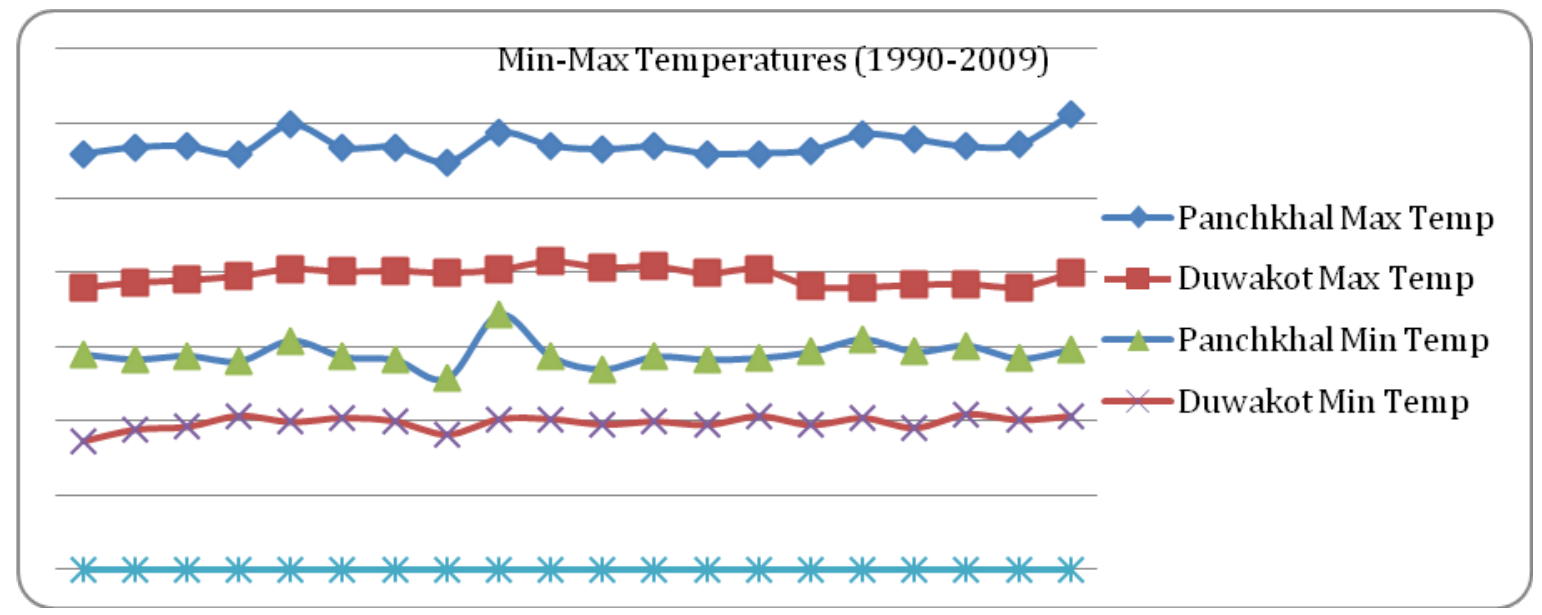

Figure 2: Min-Max Temperature (1990 - 2009) for the Panchkhal and Duwakot study sites (Source: DHMN)

Figure 3 shows that there has been a major decrease in annual rainfall (1413.5 mm to 243 $\mathrm{mm}$ ) in Bethan in the last 9 years. A similar trend, but less dramatic, was also evident in the Duwakot and Panchkhal site rainfall records (Fig. 3). Almost 94\% of respondents stated that they experienced unpredictable precipitation since 2003, with only $6 \%$ not 
identifying any change in rainfall patterns. Almost $45 \%$ of farmers noted extreme drought since 2006.

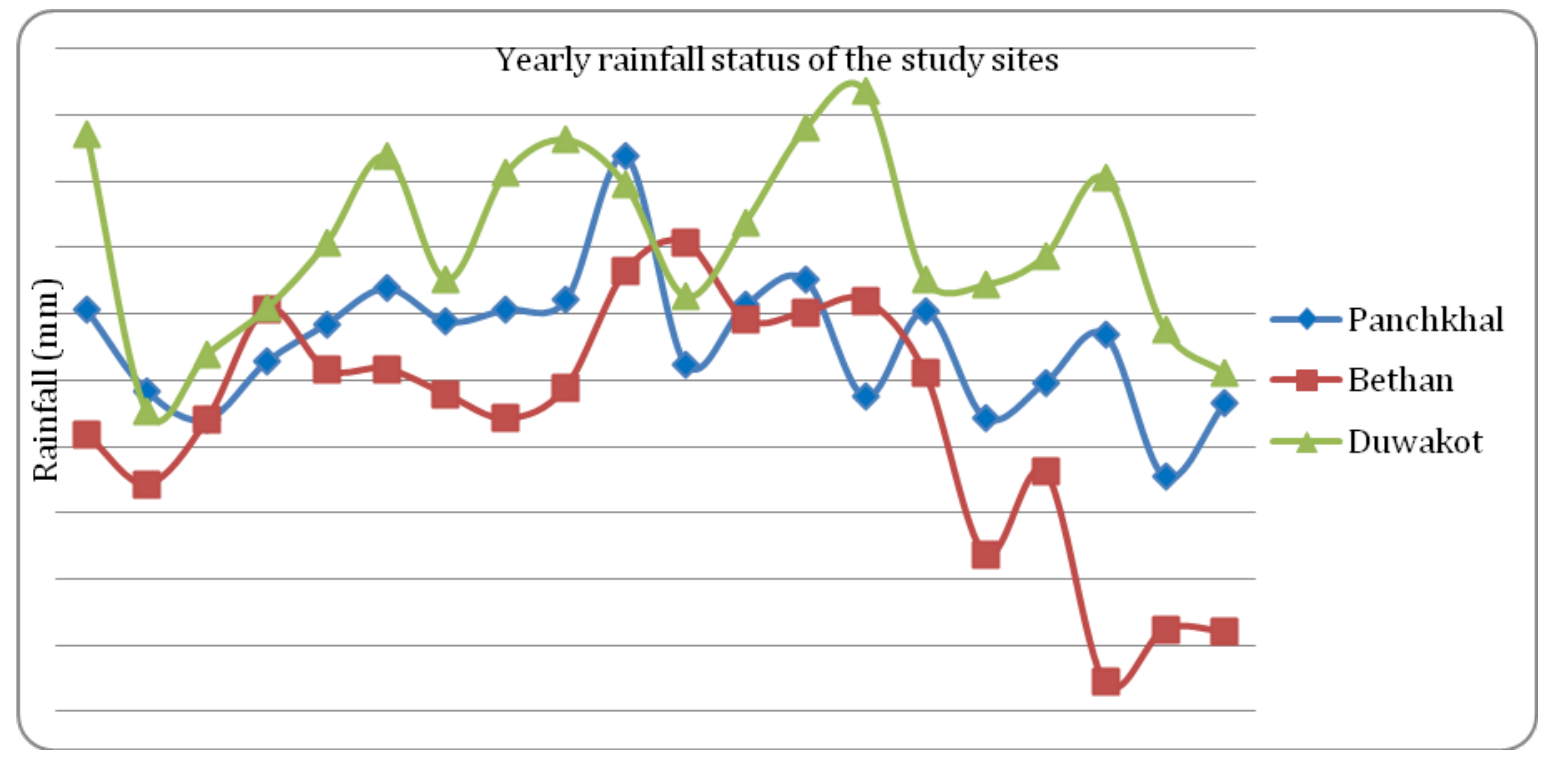

Figure 3: Yearly rainfall recorded at the three study sites in 1990-2009 (Source: DHMN)

With respect to the monsoon, the greatest concern for all rice and maize farmers was a significant decrease in rainfall quantity since 2003 (Figure 4). Interestingly, monsoon rainfall increased in 1994 and 1999. This suggests that there has been considerable interannual and seasonal variation in rainfall for which climate variability requires adaptation within the farming process; a view supported by other studies such as Shrestha (1997), Devkota et al. (2011) and Gentle and Maraseni (2012) and also by the perception of most of the older respondents in this study.

Inter-annual climate variability is a global phenomenon (Chaudhary et al., 2011; Lashkari et al., 2012). Cycles of extreme events are not only common in South Asia but also in 
African countries such as in Mozambique, Malawi, Zambia, Zimbabwe and some parts of Zimbabwe (Clay et al., 2003; Cooper et al., 2006; de Wit, 2006). In the pretext of climate change, the degree of climate variability is set to increase, and may represent a serious threat to Nepalese smallholder farmers’ livelihoods (Mubaya et al., 2012).

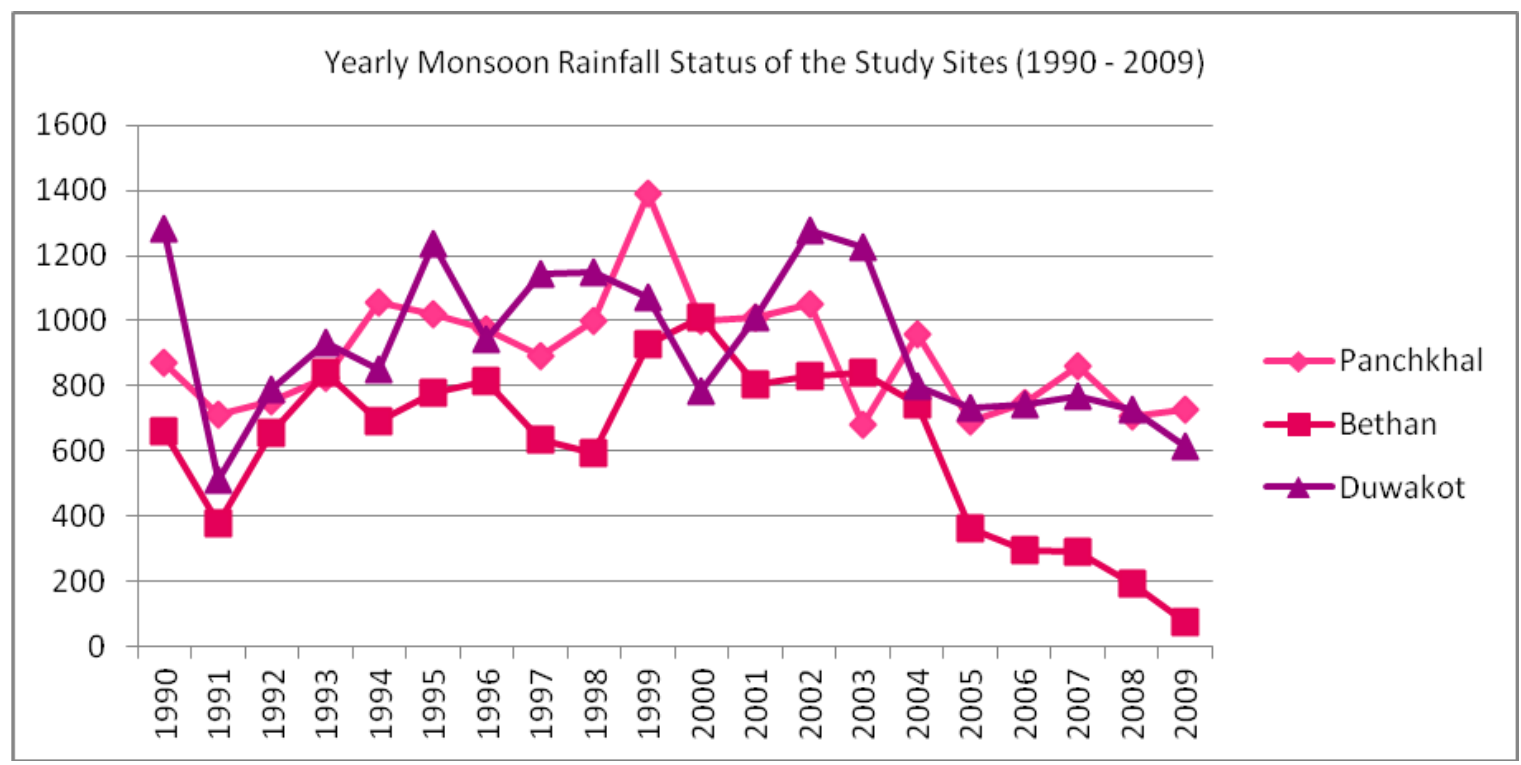

Figure 4: Monsoon rainfall measurements from the three study sites in 1990-2009 (June, July and August) (Source: DHM)

\section{1. b. Farmers' Perception on the Impacts of Climate Change}

About $85 \%$ of surveyed respondents perceived that there has been an increasing trend in temperature since 2000. The respondents also perceived a dramatic reduction in both winter temperatures and in the number of winter days. They also believed that the onset of winter has shifted from October to December. Some stated that they had not observed dense fog during winter since about 2005. They also felt that maximum temperatures had increased for five months of the year (e.g., January, March, June, September, October, and 
December) while minimum temperatures for January and March had increased considerably in 2009 as compared to 1999.

In addition, respondents found that heavy snowfalls and hailstorms have damaged crops in most years. Similarly, frequent floods, and landslides reduced arable land and increased soil structure degradation. There have been several instances of late monsoons and prolonged droughts which have severely affected the study sites that support the findings in the literature (c.f. Mubaya et al. 2012; Shrestha, 1997). In recent years, rainfall trends have fluctuated more during the monsoon, in terms of the timing, duration and quantity of rainfall, becoming more inconsistent within and between seasons causing major disruption to rain-fed farming.

\subsection{Adjustment to Climate Variability}

About $60 \%$ of farmers from all three sites have started to realize the effects of climate variability, with some adopting adaptation practices. Among the different adaptation strategies used, respondents ranked crop-related adaptations including crop rotation, change in varieties of crops, off-seasonal farming and cash crop farming as their preferred options (Table 2). Almost all farmers preferred varieties of crops that required both less time to bear fruits/grain and shorter ripening periods. There has also been an increase in cash crops, such as tomatoes (Solanum lycopersicum), onions (Allium cepa), and potatoes (Solanum tuberosum), as traditional crops such as wheat (Triticum aestivum) and paddy rice (Oryza sativa) have become less productive and less reliable in the study sites. 
Nepal's farmers traditionally cultivated varieties of paddy rice that used large quantities of water. About $87 \%$ of farmers have replaced these with new paddy varieties that require less water on both irrigated and non-irrigated land (Table 2). Similarly, they have started sowing red wheat that requires less water instead of the white wheat varieties. Furthermore, Musuro (Lens culinaris), a drought resistant legume which requires less water, is being preferred to traditional species. Farmers have also learnt to adapt their planting times to cope with the observed delayed onset of the monsoon. These types of typical adaptation techniques are common in this study yet they are not specifically mentioned in other studies in Nepal (c.f. Shrestha, 1997).

Table 1: Survey response to adaptation measures in agriculture in the study sites

\begin{tabular}{|lc|}
\hline Adaptation measures & Responses (\% of sample) \\
\hline Related to crop & $55(91.7 \%)$ \\
Crop rotation & $52(86.7 \%)$ \\
Change in varieties of crops & $31(51.7 \%)$ \\
Off seasonal farming & $28(46.7 \%)$ \\
Cash crop farming & \\
Related to soil & $34(56.7 \%)$ \\
Soil conservation technique & $32(53.3 \%)$ \\
Use of organic fertilizers & \\
Related to water & $22(36.7 \%)$ \\
Use of ground water & $21(35.0 \%)$ \\
Rain water harvesting & $10(16.7 \%)$ \\
Change in cultural practices & $7(11.7 \%)$ \\
Migration & $3(5.0 \%)$ \\
Change in occupation & \\
\hline
\end{tabular}


Soil erosion has detrimental effects on farm productivity. Since the 1980s, farmers have become more conscious about soil conservation techniques and begun terrace farming. Another important adaptation evident in the water sector is that some farmers (37\%) have started to use groundwater; while $35 \%$ of farmers harvested rain water from domestic ponds to irrigate their crops. Finally, in desperation, $12 \%$ of farmers have in-migrated to areas where they expect more reliable climatic conditions and economic incentives to prevail.

\subsection{Farmers' Constraints for Better Adaptation}

In order to address the adaptive capacity of farmers, Morton (2007) strongly recommended that farmers consider non-climatic factors, along with the climatic factors. Therefore, in this study, respondents were asked about the non-climatic challenges that they faced in farming. The non-climatic challenges included economic constraints, government policy and technological constraints. About $60 \%$ of farmers reported that economic constraints represented the greatest challenge; mainly the lack of government subsidies for purchasing improved seeds/crops that could sustain production even during adverse climatic conditions (Table 1). Similarly, the lack of irrigation facilities and modern technology were ranked as the second and third major challenges, respectively, for adaptation. 
Table 2: Ranked survey responses to climatic and non-climatic factors

\begin{tabular}{|cc|}
\hline Constraints & Responses (\% of sample) \\
\hline Economic constraints & $36(60.0 \%)$ \\
Income & $49(81.7 \%)$ \\
Government Policy & $37(61.7 \%)$ \\
Market & $35(58.3 \%)$ \\
Access & $31(51.7 \%)$ \\
Subsidy & $28(46.7 \%)$ \\
Irrigation problem & $31(51.7 \%)$ \\
Technological constraints & $25(41.7 \%)$ \\
Rise in temperature & $14(23.3 \%)$ \\
Fertility of soil & $10(16.7 \%)$ \\
\hline
\end{tabular}

Respondents suggested that many local landraces have vanished and some have even moved out of the study areas. Similarly, due to the early end of the monsoon, many new varieties of plants have replaced the more traditional varieties which required greater rainfall for longer periods of time. About $40 \%$ of farmers have shifted to new cropping practices which require less water. For example, local fruit species such as bananas (which consume large quantities of water) have been replaced by a variety of water-thrifty citrus crops.

\section{Discussion}

\subsection{Perception of Nepalese Survey Respondents to Climate Variability Issues}

The results reveal that climate variability has been evident both in the scientifically measured climate data (Figs. 2, 3 and 4) and in the perceptions of the local inhabitants in 
the three study sites (Tables 1 and 2). The perceptions recorded suggest that climate variability will result in adverse impacts on crop farming and farm productivity; consistent with the findings of Tiwari (2005) who concluded that the productivity of major crops in Nepal during the early 1960s was higher than most other South Asian countries. By the early 1990s, however, Nepal's agricultural productivity lagged well behind neighbouring countries, largely due to climate variability (Misra, 2013).

This study notes that people's perception about the impacts of climate variability varied considerably across the different sites. For example, people from Bethan have been facing water problems for many years. They stated that groundwater levels are usually below 30 $\mathrm{m}$ from the surface and that women and children carry water for the household from other sources $>500 \mathrm{~m}$ from their village. This made them consider localised adaptation strategies including rainwater harvesting. Unlike the outcomes of other studies, the farmers' perceptions here were more focussed on 'climatic factors' as barriers to adopt the strategies than non-climatic ones. This contradiction clearly suggests that farmers have the adaptive capacity but they lack sufficient knowledge for resource distribution. There is no doubt that local strategies are working to the advantage of local farmers and the local communities. The only requirement needed is policy makers developing a knowledge platform to collect and disseminate the strategies.

\subsection{Role of Government and Non-Government Bodies}

The Government of Nepal implemented various climate change strategies since 2008 for the identified high climate-related risk factors of water quality/quantity, food security and 
ecosystem health, in partnership with various NGO's and donors. Moreover, Nepal has successfully prepared a Climate Change Policy and National Adaptation Programme of Actions (NAPA) - made public in September 2010 - representing the first comprehensive climate change-dedicated government policy document. Although, NAPA has spurred the Nepalese Government to allocate significant resources into six line ministries, it fails to allocate roles and to specify actions needed by local communities (Helvetas Swiss Intercooperation, 2011). Forthcoming climate change policies and programmes may help to rectify this situation.

The National Capacity Self-Assessment Study of Nepal highlighted a lack of institutional capacity and poor co-ordination (Saito, 2012) among governmental and nongovernmental agencies in dealing with issues related to climate change, and also identified vested interests of organizations to address climate change issues. They (for example: NAPA studies) used a top-down approach to allocate resources that represents an inefficient way to capture local knowledge of adaptation. Similarly, the concerns of stakeholders and government are more relied on in international studies of impacts and mitigation, but are negligible in locally-led adaptation techniques. The farmers' perceptions gave some insight into the need to implement a knowledge bank where meteorological data are relatively poor.

Finally, a Multi-stakeholder Climate Change Initiatives Co-ordination Committee (MCCICC) was also formed in 2010. This Committee is chaired by the Secretary of the Ministry of Environment, involving 38 members across government, local governments, 
academia, development partners and NGO's, aims to promote a functional level of coordination and information sharing (Bird, 2011). However, this committee does not have any provision for representation from the community. The findings of this study clearly show that such a policy without community participation may lead to more devastating outcomes in the future.

\section{Conclusions and Recommendations}

Using a bottom-up approach, this study analysed the bio-physical and socio-economic impacts on Nepalese agriculture derived from focus group discussions and a survey of peasant farmers to identify relevant climate change impacts from which farmers’ practices in overcoming climate-based barriers could be investigated. Results from the case studies highlight that Nepalese farmers have identified climatic impacts in their environment. An examination of rainfall for 1990 to 2009 and temperature data also showed marked variations, particularly evident in the last 10 years. There appears to be an enhanced interannual and seasonal variation in rainfall, suggesting that climate variability is an issue and that Nepalese farming adaptation strategies should be a high priority, with more droughtresistant, high yielding crop varieties currently being the farmer’s number one priority.

Nepalese farmers have been changing their cropping patterns and agricultural practices in response to climate variability. Although both climatic and non-climatic factors are important to them, the non-climatic factors such as alternative income generation activities, poor government policy, limited farm subsidies and refinement of locally emerging adaptation technologies, were seen as very important. Therefore, government 
attention should focus on both non-climatic and climatic factors with some potential solutions being:

* Forming a community-based seed bank to assist farmers in changing their onseasonal and off-seasonal farming patterns

* Government co-ordination with peasant farmers in developing subsidy policies

* Developing impact and adaptation assessment and educational programs to help improve awareness and action for peasant farmers

Farmers have already initiated some useful adaptation practices on their own without any support from government or any other organisation. These adaptation practices, if effective, should be preserved and transferred to the next generation of farmers.

\section{Acknowledgement}

We cordially thank all respondents for their highly valuable time and suggestions. We would also like to thank Habib Zafarullah for his comments on this paper. We also sincerely thank the anonymous referees for their valuable suggestions that have greatly improved the final manuscript.

\section{References}

Agrawala S., Raksakulthai V., van Aalst, M., Larsen, P., Smith, J. and Reynolds, J. (2003) Development and climate change in Nepal: focus on water resources and hydropower. [Online] Paris Organisation for Economic Co-operation \& Development, http://calclimate.berkeley.edu/sites/default/files/OECD_Nepal_Hydropower_2003. pdf (Accessed 10 April 2013). 
Ahmed, F., Al-Amin, A.Q. and Alam, G.M. (2012) Climate change issues: challenges for Natural Resource Management in Bangladesh - a way forward, International Journal of Global Warming, Vol. 4, No. 1, pp. 68-80.

Al-Amin, A.Q. and Filho, W.L. (2012) 'Towards long-term climate change mitigation: the role of low-carbon growth planning', Int. J. Global Warming, Vol. 4, No. 1, pp. 81-90.

Bhandari, G (2013) Assessment of Climate Change Impacts and Adaptation Measures in the Kapilbastu District of Nepal. Applied Ecology and Environmental Sciences, 1(5), 75-83. doi: 10.12691/aees-1-5-2

Bird, N. (2011) The future for climate finance in Nepal, Overseas Development Agency. http://www.odi.org.uk/sites/odi.org.uk/files/odi-assets/publications-opinionfiles/7191.pdf (Accessed 9 April 2013).

Bryan, E., Ringler, C., Okoba, B., Roncoli, C., Silvestri, S., and Herrero, M. (2013). Adapting agriculture to climate change in Kenya: household strategies and determinants. Journal of Environmental Management, 114, 26-35. doi: 10.1016/j.jenvman.2012.10.036

Bryman, A. (2008) Social Research Methods, Oxford, New York.

Burton, I. (1996) Vulnerability and adaptive response in the context of climate and climate change, Climatic Change, Vol. 36, pp. 185-196.

Chalise, S. (2012) Combating Climate Change: A Real Threat to Nepal, Lambert Academic Publishing, Germany.

Chaudhary, Pashupati, Rai, Suman, Siddhant Wangdi, Akai Mao, Rehman, Nishat, Chettri, Santosh, \& Bawa, Kamaljit S. (2011). Consistency of local perceptions of climate change in the Kangchenjunga Himalaya landscape. Current Science, 101(4), 504-513.

Claessens, L., Antle, J. M., Stoorvogel, J. J., Valdivia, R. O., Thornton, P. K., and Herrero, M. (2012). A method for evaluating climate change adaptation strategies for smallscale farmers using survey, experimental and modeled data. Agricultural Systems, 111, 85-95. doi: 10.1016/j.agsy.2012.05.003

Clay, E., Bohn, L., der Armas, E.B., Kabambe, S. and Tchale, H. (2003) Malawi and Southern Africa: climate variability and economic performance, Working Paper Series No. 7, Disaster Risk Management. 
Cooper, J.P.M., Dimes, J., Rao, K.P.C., Shapiro, B., Shiferaw, B., Twomlow, S. (2006) Coping better with current climate variability in the rain-fed farming systems of Sub-Saharan Africa: a dress rehearsal for adapting to future climate change?, Global theme on agro ecosystems. Report no 27, International Crops Research Institute for the Semi-Arid Tropics, Bulawayo, Zimbabwe.

Deressa, T., Tadesse, H., Rashid M., Ringler, Claudia, Alemu, Tekie, and Yesuf, M (2009) Determinants of farmers' choice of adaptation methods to climate change in the Nile Basin of Ethiopia. Global Environmental Change, 19(2), 248-255. doi: 10.1016/j.gloenvcha.2009.01.002.

Devkota, R.P, Bajracharya, B, Maraseni, T.N, Cockfield, G, and Upadhyay, B.P. (2011) The perception of Nepal's Tharu community in regard to climate change and its impacts of their livelihoods, International Journal of Environmental Studies, Vol.68, pp. 936-947.

de Wit, M. (2006) Climate change and African agriculture. http://www.ceepa.co.za/docs/POLICY\%2520NOTE\%252011.pdf （Accessed 9 April 2012).

Esham, Mohamed, \& Garforth, Chris. (2013). Agricultural adaptation to climate change: insights from a farming community in Sri Lanka. Mitigation and Adaptation Strategies for Global Change, 18(5), 535-549. doi: 10.1007/s11027-012-9374-6

FAO (Food and Agriculture Organisation) (2004) Poverty, livestock and household typologies in Nepal. [online] ESA Working Paper No. 04-15. ftp://ftp.fao.org/docrep/fao/007/ae125e/ae125e00.pdf (Accessed 9 April 2012).

Fischer, G., Shah, M., Tubiello, F. N. and van Velthuizen, H. (2005) Socio- economic and climate change impacts on agriculture: an integrated assessment, 1990-2080', Philosophical Transactions of the Royal Society B., Vol. 360 (1463), pp. 20672083.

Gentle, P. and Maraseni, T. N. (2012) Climate change, poverty and livelihoods: Adaptation practices by rural mountain communities in Nepal, Environmental Science and Policy, Vol. 21, pp. 24-34.

Gurung, G.B. and Bhandari, D. (2009) Integrated Approach to Climate Change Adaptation, Journal of Forest and Livelihood, Vol. 8 (1), pp. 91-99.

Guzman, R. B. (2006) Climate Change and its implications for small farmers, Teh Chun Hong - Production (PAN AP).

HELVETAS Swiss Intercooperation (2011) Nepal's climate change policies and plans: local communities' perspective environment and climate series 2011/1. Kathmandu, Nepal, 32pp. 
IPCC (Intergovernmental Panel on Climate Change) (1996) Climate Change 1995Impacts, adaptations and mitigation of climate change: scientific technical analyses. Contribution of working group II to the second assessment report of the Intergovernmental Panel on Climate Change.

IPCC (1998) The regional impacts of climate change: an assessment of vulnerability. [online] Intergovernmental Panel on Climate Change (IPCC) Summary for Policymaker, Cambridge. http://www.ipcc.ch (Accessed 9 April 2012).

Jenny, A.L. and Egal, F. (2002) Household food security and nutrition in mountain areas: an often forgotten story. Nutrition programmes service, FAO-ESNP, Rome, 17 pp.

Karki M. (2008) Nepal economic growth assessment, agriculture - A report submitted to USAID, Kathmandu.

Karki, R. \& Gurung, A (2012) An Overview of Climate Change And Its Impact on Agriculture: a Review From Least Developing Country, Nepal. International Journal of Ecosystem, 2(2), 19-24. doi: 10.5923/j.ije.20120202.03

Lashkari A., Alizadeh A., Rezaei E.E., and Bannayan, M. (2012) Mitigation of climate change impacts on maize productivity in northeast of Iran: a simulation study. Mitigation and Adaptation Strategy for Global Change, Vol. 17, pp.1-16.

Malla, G. (2008). Climate change and its impact on Nepalese Agriculture. The Journal of Agriculture and Environment, 9, 62-71.

Misra, AnilKumar. (2013). Climate change impact, mitigation and adaptation strategies for agricultural and water resources, in Ganga Plain (India). Mitigation and Adaptation Strategies for Global Change, 18(5), 673-689. doi: 10.1007/s11027012-9381-7.

Ministry of Agriculture and Co-operatives. (2005) Statistical information on Nepalese agriculture. Time Series Information, Kathmandu, Nepal.

Morton, J.F. (2007) The impact of climate change on smallholder and subsistence agriculture, PNAS, Vol. 104 (50), pp. 19680-19685.

Mubaya, C.P., Njuki, J., Mutsvangwa, E.P., Mugabe, F.T. and Nanja, D. (2012) Climate variability and change or multiple stressors? farmer perceptions regarding threats to livelihoods in Zimbabwe and Zambia, Journal of Environmental Management, Vol. 102, pp. 9-17.

Qiu Z., and Prato T. (2012) Economic feasibility of adapting crop enterprises to future climate change: a case study of flexible scheduling and irrigation for representative 
farms in Flathead Valley, Montana, USA, Mitigation and Adaptation Strategy for Global Change, Vol. 17, pp. 223-242.

Saito N. (2012) Mainstreaming climate change adaptation in least developed countries in South and Southeast Asia, Mitigation and Adaptation Strategy for Global Change, DOI 10.1007/s11027-012-9392-4.

Shrestha, M.L. (1997) Development of Climate Change Scenarios with Reference to Nepal. In: Proceedings of the Workshop on Climate Change in Nepal, 25 June 1997, Kathmandu.

Tiwari, M. (2005) Marginal farmers, agricultural practices, and rural poverty in Nepal, Jahrbuch der Österreichischen Gesellschaft für Agrarökonomie 12: 123-147

Yin, R.K. (2003) Case study research: Design and methods, Sage Publications, Inc. 